\title{
STUDI PENGGUNAAN DETEKTOR GELEMBUNG SEBAGAI DOSIMETER DAN DETEKTOR KEKRITISAN
}

\author{
Sjafruddin \\ Pusat Teknologi Bahan Bakar Nuklir - BATAN, Kawasan Puspiptek, Serpong, 15312
}

\begin{abstract}
ABSTRAK
Suatu studi terhadap detektor gelembung untuk digunakan sebagai dosimeter dan detektor kekritisan nuklir telah dilakukan. Metoda studi adalah dengan cara menginvestigasi karakteristik dari detektor gelembung terhadap radiasi netron untuk mendapatkan kelebihannya sebagai dosimeter netron dan kemungkinan pengembangannya sebagai detektor kekritisan. Hasil investigasi menunjukkan bahwa detektor gelembung jenis $B D-100$ dan $B D-100$ R sensitif terhadap netron cepat, tidak sensitif terhadap gamma, responnya cepat, dapat digunakan berulang untuk jenis $B D-100 R$, dosis radiasi dapat dibaca secara langsung dan jumlah gelembung sebanding dengan besar dosis. Batas dosis tertinggi untuk tipe BR-100R (1.5) dan BD-100R (3.3) berturutturut adalah 180 mrem dan 560 mrem. Indikator bunyi akustik yang ditimbulkan oleh interaksi netron pada tetesan mikroskopik cairan superheated dapat dimanfaatkan untuk mengembangkannya sebagai detektor kekritisan nuklir.
\end{abstract}

Kata kunci : detektor gelembung, cairan superheated, kecelakaan kekritisan.

\begin{abstract}
STUDY ON BUBBLE DETECTOR AS DOSIMETER AND NUCLEAR CRITICALITY DETECTOR. A study on bubble detector to be used as dosimeter and nuclear criticality detector has been done. Study method is by mean investigating the bubble detector characteristics against neutron radiation to obtain its expectation as neutron dosimeter and criticality detector. Investigation results shows that bubble detector type BD-100 and BD-100R have sensitive to fast neutron, not sensitive to gamma ray, rapid response, reusable (type BD-100R), directly reading doses and number of bubble proportional to dose. Upper limit doses of BD-100R (1.5) and BD-I00R (3.3) respectively were 180 mrem and 560 mrem. Acoustic sound indicators produced by neutron interactions on microscopic drops of superheated liquid can be used to develop as nuclear criticality detector.
\end{abstract}

Keywords: Bubble detector, superheated liquid, criticality accident

\section{PENDAHULUAN}

Sejak dikembangkan oleh Bubble Technology Inc. dan Apfel Enterprises Company sehingga menjadi detektor netron yang praktis, sederhana dan cepat, detector gelembung telah memberikan harapan yang baik sebagai dosimeter netron. Hal ini karena dosimeter netron pendahulunya memiliki beberapa kekurangan yang tidak dapat dipenuhi untuk keperluan secara umum pada pemakaian sebagai dosimeter personil. Tiga jenis dosimeter personil netron yang biasa digunakan sebelum detector gelembung diperkenalkan, yaitu: plastic/ film netron type A (NTA film), dosimeter Albedo termoluminisensi (TLD Albedo) dan detektor jejak fisi (fission track detector) memiliki masalah pada respon atau sensitivitas terhadap energi netron dan adanya pemudaran (fading), pemakaian bahan radioaktif, perlu proses lebih lanjaut untuk membaca dosis dan keterbatasan lainnya ${ }^{[1]}$. Kemudian dipromosikan dosimeter netron plastik CR-39 untuk 
memenuhi kekurangan pada dosimeter NTA film, yaitu CR-39 memiliki keunggulan tidak sensitif terhadap radiasi gamma dan tidak ada pemudaran, tetapi tidak sensitif terhadap netron thermal.

Detektor gelembung yang dibahas dalam tulisan ini dapat mengatasi kekurangan-kekurangan yang ada pada keempat jenis dosimeter personil netron tersebut di atas. Pada tulisan ini akan dikaji keunggulan detektor gelembung sebagai dosimeter personil netron dan beberapa karakteristik detektor gelembung diperiksa untuk keperluan pemantauan dosis netron. Karakteristik detektor gelembung dalam mendeteksi radiasi netron berupa bunyi (suara akustik) dan respon yang cepat (seketika) dapat dimanfaatkan dan dikembangkan sebagai detektor personil atau area untuk memantau kecelakaan seperti kecelakaan kekritisan bahan fisil yang memancarkan radiasi netron.

Ada empat detektor netron yang telah biasa dipakai untuk keperluan proteksi radiasi atau dosimeter personil sebelum detektor gelembung diperkenalkan sebagai dosimeter netron. Walaupun telah secara luas digunakan, tinjauan terhadap karakteristik keempat detektor tersebut dalam mendeteksi radiasi netron tidak memberikan kepuasan untuk digunakan sebagai dosimeter personil dan pemakaian secara umum. Kekurangan yang dimiliki keempat detektor netron pendahulu detektor gelembung diuraikan berikut ini.

Detektor netron TLD Albedo tidak memiliki respon atau sensitivitas terhadap rentang energi netron yang lebar. Detektor ini tidak sensitif terhadap netron cepat. Selain sensitif terhadap netron thermal, TLD Albedo juga sensitif terhadap radiasi gamma. Jadi untuk mengukur radiasi netron thermal melalui reaksi dengan unsur $\mathrm{Li}^{6}$ dalam TLD, TLD Albedo harus dikombinasikan dengan pasangannya yang sensitif terhadap radiasi gamma saja (TLD $\mathrm{Li}^{7}$ ) untuk eliminasi dosis radiasi gamma.

Detektor netron NTA film tidak sensitif terhadap netron thermal dan sensitif terhadap radiasi gamma. Kekurangan lain dari NTA film adalah adanya pemudaran dari hasil pemantauan pada film sehingga harus ditangani secara hati-hati.

Detektor jejak fisi memiliki respon yang baik terhadap rentang energi netron dari energi thermal sampai cepat dan tidak sensitif terhadap radiasi gamma, namun kekurangannya adalah adanya penggunaan bahan radioaktif sehingga memberikan tambahan dosis pada personil saat menggunakannya. Oleh sebab itu penggunaan detektor jejak fisi ditinggalkan sebagai dosimeter personil, tetapi tetap dipertahankan sebagai detektor pemantau area kerja.

Detektor netron CR-39 berhasil mengatasi beberapa kekurangan dari detektor NTA film. CR39 tidak sensitif terhadap radiasi gamma dan tidak ada problem fading, namun detektor ini hanya sensitif terhadap netron cepat.

Dari segi pendeteksian radiasi netron dapat dikatakan bahwa persyaratan dosimeter netron yang diinginkan adalah memiliki sensitivitas yang lebar pada rentang energi netron, yaitu mulai dari energi netron thermal sampai cepat, dan tidak sensitif terhadap radiasi gamma. Di antara karakter keempat detektor netron di atas hanya detektor jejak fisi yang memenuhi persyaratan, namun adanya pemakaian bahan radioaktif menyebabkan detektor ini tidak cocok sebagai dosimeter untuk keperluan personil.

Kekurangan mendasar dimiliki keempat detektor netron di atas adalah bahwa untuk membaca dosis radiasi diperlukan proses lebih lanjut dan alat bantu pembaca dosis serta tidak dapat digunakan secara berulang. Kekurangan ini menyebabkan biaya operasional meningkat, memerlukan waktu untuk membaca dosis dan tidak praktis.

Detektor gelembung dapat mengatasi semua permasalahan di atas. Selain memiliki respon terhadap rentang energi netron dari termal sampai cepat, detector gelembung tidak sensitif terhadap radiasi gamma ${ }^{[2]}$. Sebagai dosimeter netron personil, detektor gelembung memiliki respon energi netron yang dekat dengan kurva dosis ekivalen yang direkomendasikan International Commission on Radiation Protection (ICRP) ${ }^{[3]}$. Detektor ini tidak mengandung bahan radioaktif, tidak ada masalah pemudaran, dapat digunakan ulang untuk jenis tertentu, memiliki respon yang cepat (seketika), dosis netron dapat dibaca secara langsung tanpa perlu proses lebih lanjut, kecil dan ringan (silinder dimensi: diameter $16 \mathrm{~mm}$, tinggi 80 $\mathrm{mm}$ dan berat $20 \mathrm{~g}$ ) sehingga dapat dikaitkan pada saku baju kerja dan praktis dalam penggunaannya. Dalam tulisan ini diperiksa karakteristik lain dari detektor gelembung untuk keperluan penggunaan sebagai dosimeter dan detektor kekritisan.

Detektor gelembung dikembangkan berdasarkan prinsip kerja dari kamar gelembung (bubble chamber) yang ditemukan fisikawan D.A. Glaser pada tahun 1952. Pada alat ini gelembung yang terbentuk akibat radiasi pengion dapat bergerak dalam cairan sensitif menuju permukaan cairan sehingga lepas ke udara. Saat gelembung terbentuk, gambarnya diambil dengan kamera foto untuk keperluan menghitung dosis radiasi.

Perkembangan pesat pada detektor radiasi pengion seperti detector Geiger Muller, Proporsional Counter dan Kamar Ionisasi menyebabkan prinsip kerja kamar gelembung tidak popular. Pada tahun 1979 muncul ide dari R.E. Apfel untuk memperbaiki prinsip kerja kamar gelembung sehingga dapat digunakan secara praktis sebagai detektor pengukur radiasi. Apfel mengusulkan untuk menjebak gelembung yang terbentuk akibat radiasi pengion dalam suatu media 
semi padat transparan (gelatin) sehingga gelembung tersebut tidak bergerak dan tetap pada posisi terbentuknya. Gelembung kasat mata yang terjebak dalam media gelatin transparan dapat dihitung secara langsung untuk menentukan besarnya dosis dari radiasi pengion. Ide ini berhasil dilaksanakan sehingga terbentuk detektor jenis baru yang disebut detektor gelembung. Selanjutnya detektor ini diteliti karakteristiknya untuk berbagai keperluan diantaranya untuk dosimeter netron personil.

Detektor gelembung yang dikenal sebagai Bubble Detector (BD) untuk nama dagang dari Bubble Technologi Inc. (BTI) atau Superheated Drop Detector (SDD) untuk nama dagang dari Apfel Interprises terbuat dari bahan semi padat seperti polimer atau gel sebagai media perangkap gelembung. Dalam gel tersebar secara merata tetesan-tetesan kecil (diameter sekitar $25 \mu \mathrm{m}$ ) cairan yang sensitif terhadap radiasi. Setiap tetesan independen (tidak terhubung dengan tetesan lainnya) sehingga gelembung yang terbentuk, terperangkap dan kasat mata dapat dihitung dengan mudah.

Jenis cairan sensitif radiasi atau dikenal sebagai superheated liquid dalam detektor gelembung menentukan karakteristik pendeteksian radiasi. Untuk detektor yang sensitif terhadap netron umumnya digunakan cairan Freon sebagai superheated liquid. Ada empat jenis bahan superheated liquid yang telah diselidiki seperti yang ditampilkan pada table berikut, namun hanya jenis Freon-12 yang memiliki sensitivitas baik terhadap rentang energi netron dari thermal sampai cepat.

Tabel-1. Sifat fisika bahan superheated liquid detector gelembung pada temperature ruang ${ }^{[2]}$.

\begin{tabular}{cccccc}
\hline $\begin{array}{c}\text { Nama } \\
\text { Dagang }\end{array}$ & $\begin{array}{c}\text { Rumus } \\
\text { Kimia }\end{array}$ & $\begin{array}{c}\text { Titik } \\
\text { Didih }\left({ }^{0} \mathrm{C}\right)\end{array}$ & $\begin{array}{c}\text { Tekanan Uap } \\
(\mathbf{a t m})\end{array}$ & $\begin{array}{c}\text { Kerapatan } \\
\left(\mathrm{g} / \mathbf{c m}^{3}\right)\end{array}$ & $\begin{array}{c}\text { Rentang Energi } \\
\text { Netron }(\mathbf{M e V})\end{array}$ \\
\hline Freon-12 & $\mathrm{CCl}_{2} \mathrm{~F}_{2}$ & $-29,8$ & 5,8 & 1,3 & $2,5 \times 10^{-8}$ sampai 14,0 \\
Freon-114 & $\mathrm{C}_{2} \mathrm{Cl}_{2} \mathrm{~F}_{4}$ & 3,5 & 1,9 & 1,5 & 5,9 sampai 14,0 \\
Freon-142B & $\mathrm{C}_{2} \mathrm{H}_{3} \mathrm{ClF}$ & $-9,3$ & 3,0 & 1,1 & 3,0 sampai 14,0 \\
Isobutana & $\mathrm{C}_{4} \mathrm{H}_{10}$ & $-11,7$ & 3,1 & 0,6 & 2,0 sampai 14,0 \\
\hline
\end{tabular}

Prinsip pendeteksian radiasi netron pada detektor gelembung merupakan peristiwa reaksi antara netron dengan cairan sensitif sehingga menyebabkan cairan tersebut mendidih, menguap dan meletus sehingga terbentuk gelembung yang terperangkap dalam gel dalam waktu yang sangat singkat. Bila yang menumbuk cairan sensitif adalah netron thermal maka terbentuk partikel bermuatan sekunder (secondary charge particle) seperti reaksi nuklir berikut:

$$
\mathrm{Cl}^{35}(\mathrm{n}, \mathrm{p}) \mathrm{S}^{35}
$$

Proton (p) yang terbentuk dalam reaksi nuklir tersebut dengan energi $615 \mathrm{keV}$ mampu mendidihkan cairan sensitif sehingga meletus membentuk gelembung. Bila yang menumbuk cairan sensitif adalah netron cepat maka terjadi peristiwa hamburan elastik (elastic scattering) yang menghasilkan inti rekoil (recoil nucleus) berenergi. Inti rekoil menumbuk elektron pada atom dan elektron berenergi tersebut dapat mendidihkan cairan sensitif sehingga meletus membentuk gelembung. Peristiwa ini yang dikenal sebagai Spike Theory ${ }^{[2]}$.

Untuk menghitung dosis radiasi netron suatu model persamaan matematis berikut digunakan:

$$
\mathrm{B}=\psi \mathrm{V} \sigma(\mathrm{En}) \text { No } \rho / \mathrm{M} \text {. }
$$

B adalah laju pertumbuhan gelembung (gelembung/detik), $\psi$ dan $\mathrm{V}$ berturut-turut adalah fluks netron (netron $/ \mathrm{cm}^{2}$-detik) dan volume total cairan sensitif $\left(\mathrm{cm}^{3}\right), \sigma(E n)$ adalah penampang lintang (cross section) reaksi sebagai fungsi dari energi netron, No adalah bilangan Avogadro, $\rho$ adalah kerapatan massa cairan sensitif $\left(\mathrm{g} / \mathrm{cm}^{3}\right)$ dan $\mathrm{M}$ adalah berat molekul. B proporsional dengan laju dosis radiasi netron atau dengan kata lain jumlah gelembung yang terbentuk sebanding dengan besarnya dosis netron. Berdasarkan persamaan di atas dapat dilihat bahwa sensitivitas dari detector gelembung dapat diatur dengan variasi volume cairan sensitif dan sensitivitasnya akan berkurang dengan menurunnya volume cairan sensitif atau menurunnya jumlah tetesan cairan di dalam detektor. Dengan demikian detektor gelembung memiliki batas pemakaian yang ditandai batas akumulasi dosis tertinggi yang mampu dideteksi (upper limit dose) akibat berkurangnya jumlah tetesan. Pada tulisan ini juga diperiksa batas dosis tersebut dan karakteristik lainnya untuk keperluan dosimetri dan detektor kecelakaan. 


\section{METODE}

Eksperimen Pemeriksaan Karakteristik Detektor Gelembung.

Pemeriksaan karakteristik detektor gelembung dilakukan terhadap dua jenis detektor, yaitu BD-100 dan BD-100R yang pada label detektor tertera BD100 (2.7), BD-100R (1.5) dan BD-100R (3.3). Angka dalam kurung menandakan sensitivitas detektor gelembung dalam satuan $\mathrm{mrem} /$ gelembung. Masing-masing jenis dan sensitivitas tersedia tiga buah detektor sehingga ada sembilan detektor yang digunakan. Suatu alat pengompres juga digunakan untuk menghilangkan gelembung yang terjebak di dalam gel. Detektor disinari dengan sumber radioaktif pemancar netron cepat $\mathrm{Cf}^{252}$ yang diketahui emisi fluksnya pada jarak $20 \mathrm{~cm}, 30 \mathrm{~cm}$ dan $40 \mathrm{~cm}$ dari sumber tanpa ada yang menghalangi. Variasi posisi penyinaran juga dilakukan terhadap detektor dan penyinaran dilakukan selama dua jam. Temperatur ruangan tempat penyinaran juga dijaga stabil karena ternyata sensitivitasnya juga dipengaruhi oleh temperatur ruangan. Dalam eksperimen ini dilakukan penyinaran pada temperatur sekitar $20-21^{\circ} \mathrm{C}$. Suatu grafik sensitivitas terhadap temperatur dari produsen detektor juga digunakan untuk pelaksanaan eksperimen. Selesai penyinaran jumlah gelembung kasat mata dalam gel transparan dihitung jumlahnya dan dikonversikan ke dalam satuan dosis netron (mrem). Untuk pemakaian selanjutnya kedua jenis detektor diberi tekanan menggunakan alat pengompres genggam agar gelembung hilang sehingga tidak menyulitkan penghitungan gelembung dari hasil penyinaran berikutnya.

\section{HASIL DAN PEMBAHASAN}

Hasil pengamatan terhadap karakteristik detektor gelembung yang digunakan menunjukkan bahwa kedua jenis detektor sensitif terhadap radiasi netron cepat yang berasal dari sumber radioaktif $\mathrm{Cf}^{252}$. Pengamatan respon detektor terhadap netron thermal tidak dilakukan karena keterbatasan sumber penyinaran. Setelah penyinaran netron, pada detektor terbentuk gelembung-gelembung yang dapat dihitung secara langsung seperti terlihat pada Gambar 1. Perkalian jumlah gelembung pada detektor dengan angka sensitivitas yang tertera pada label detektor merupakan besarnya dosis radiasi netron yang diterima detektor.

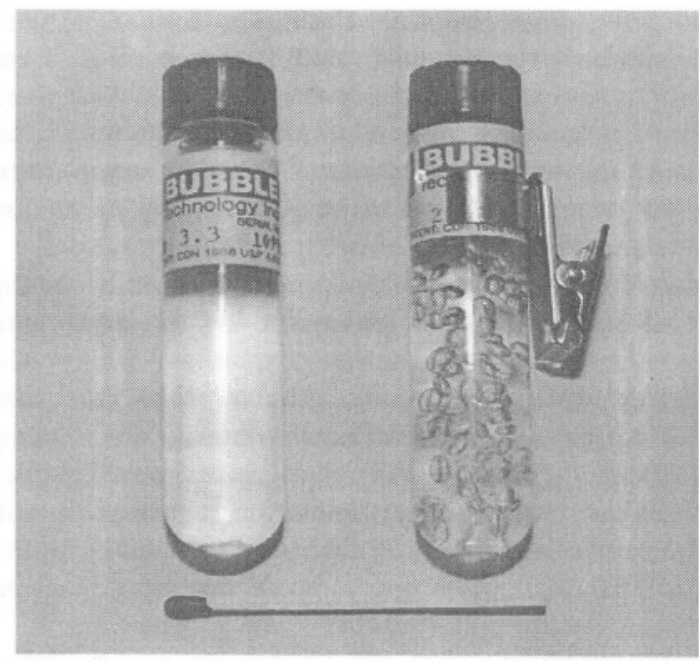

Gambar 1. Detektor gelembung sebelum (kiri) dan sesudah (kanan) penyinaran dengan netron

Gelembung terperangkap dalam gel transparan sehingga dapat dihitung secara langsung. Karakteristik lain yang teramati adalah bahwa respon detektor gelembung (dalam hal ini jumlah gelembung) terhadap variasi dosis radiasi netron adalah sebanding (proporsional) dan diperoleh kurva yang lurus untuk sejumlah akumulasi dosis. Namun pada jumlah dosis tertentu kurva menjadi tidak linier akibat berkurangnya jumlah tetesantetesan cairan sensitif di dalam detektor. Hasil pengamatan menunjukkan bahwa batas dosis tertinggi (upper limit dose) dari detektor gelembung adalah 180 mrem untuk tipe BD-100R (1.5) dan 560 mrem untuk tipe BD-100R (3.3) ${ }^{[4]}$. Setelah mencapai dosis tersebut sensitivitas detektor berkurang secara tajam sehingga tidak dapat digunakan kembali. Sedangkan untuk tipe BD-100 tidak dilakukan pemeriksaan batas dosis tertinggi karena kesulitan saat menghitung jumlah gelembung.

Dari dua jenis detektor yang diperiksa karakteristiknya, tipe BD-100R dapat dipakai ulang dengan cara memberikan kompresi ke dalam detektor untuk menghilangkan gelembung yang sudah terbentuk, sedangkan tipe BD-100 tidak dapat dihapus gelembungnya walau telah diberi kompresi. Dengan demikian huruf $\mathrm{R}$ pada label detektor menunjukkan bahwa detektor tersebut dapat dipakai ulang (reusable)

Karakteristik yang menarik perhatian terhadap penggunaan detektor gelembung adalah adanya suara akustik saat cairan sensitif meletus akibat interaksi netron. Bunyi "tik" yang dipancarkan detektor saat tetesan sensitif meletus dapat dimanfaatkan untuk menghitung jumlah gelembung yang terbentuk ${ }^{[5]}$ selain dengan cara menghitung langsung. Namun untuk pengembangan lebih lanjut dan untuk memperluas penggunaan detektor gelembung dalam pendeteksian radiasi, 
karakteristik suara akustik dan respon yang seketika tersebut dapat juga dimanfaatkan untuk keperluan pemantauan kecelakaan yang memerlukan respon yang cepat pula. Detektor gelembung tipe BD-100 atau BD-100R memungkinkan untuk digunakan sebagai detektor pemantau kecelakaan radiasi, khususnya detektor kecelakaan kekritisan yang memancarkan radiasi netron baik untuk personil maupun area. Detektor dapat dikombinasikan dengan suatu suatu mikrofon untuk menangkap suara akustik dan kemudian diperkuat dengan amplifier dan disalurkan ke alat indikator suara (speaker headset atau sirine). Desain blok diagram sistem deteksi kecelakaan tersebut dapat dilihat pada Gambar-2.

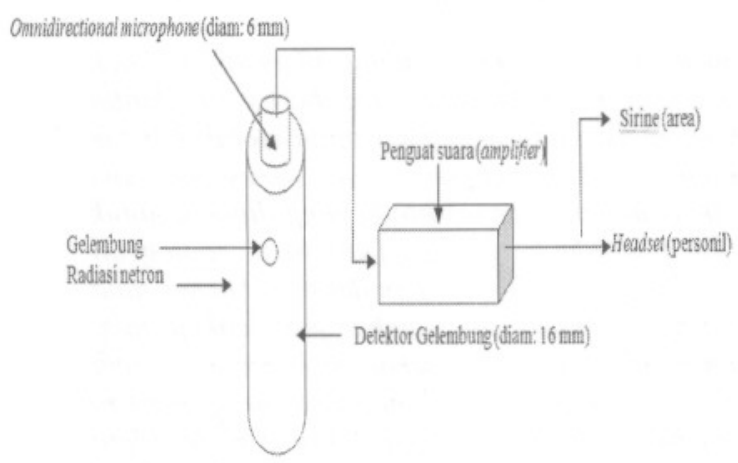

Gambar 2. Blok diagram sistem deteksi Pendeteksi kecelakaan kekritisan menggunakan detektor gelembung

Mekanisme sistem pendeteksi kecelakaan seperti diagram di atas adalah ketika netron menumbuk tetesan larutan sensitif secara spontan tetesan meletus dan mengeluarkan bunyi akustik yang ditangkap oleh omnidirectional microphone. Ini adalah mikrofon yang hanya menangkap bunyi dari satu arah sehingga tidak terpengaruh oleh suara dari sisi-sisinya. Mikrofon yang berukuran kecil dipasang pada bagian atas detektor gelembung mampu menangkap suara dengan frekuensi $20 \mathrm{~Hz}-$ $1 \mathrm{KHz}$. Mikrofon seperti ini telah tersedia dipasaran saat ini. Suara yang ditangkap oleh mikrofon diperkuat oleh suatu amplifier dan disalurkan ke sistem sirine untuk pemantauan area atau ke headset untuk dipakai oleh personil. Desain seperti walkman memungkinkan dibuat dan digunakan oleh personil untuk mengetahui dengan cepat adanya peristiwa kecelakaan kekritisan. Dengan adanya indikator suara yang didengar personil, dalam situasi kecelakaan personil dapat melakukan tindakan segera untuk evakuasi menghindari sumber kecelakaan atau sumber radiasi netron.

\section{KESIMPULAN}

Berdasarkan hasil studi yang dilakukan dapat disimpulkan bahwa detektor gelembung cocok digunakan sebagai dosimeter personil karena keunggulan sensitivitas terhadap rentang energi netron dari thermal sampai cepat serta tidak sensitif terhadap radiasi gamma. Keunggulan lainnya adalah kemudahan penggunaan seperti praktis, tidak memerlukan proses lanjut untuk membaca dosis, dapat dipakai ulang (BD-100R) dan memiliki respon cepat sehingga cocok juga untuk digunakan sebagai detektor kecelakaan.

Hasil pemeriksaan terhadap karakteristik detektor gelembung menunjukkan bahwa jumlah gelembung yang dihasilkan dari radiasi netron proporsional dengan besar dosis yang diterima dan pada akumulasi dosis tertentu responnya linear. Respon berkurang secara tajam setelah mencapai upper limit dose sebesar 180 mrem untuk BD-100R (1.5) dan 560 mrem untuk BD-100R (3.3).

Untuk keperluan pengembangan sebagai detektor kecelakaan, khususnya kecelakaan kekritisan yang memancarkan radiasi netron maka detektor gelembung memungkinkan untuk digunakan. Desain yang disampaikan dalam tulisan ini memungkinkan untuk direalisasaikan (dibuat) karena komponen-komponen untuk itu tersedia saat ini di pasar.

\section{DAFTAR PUSTAKA}

1. Griffith R.V. et. al, Recent Developments in Personnel Neutron Dosimetry: A Review, Health Physics, Vol. 36 (1979) 235-260.

2. Apfel, R.E., Photon Insensitive, Thermal to Fast Neutron Detector, Nuclear Instrument Method, Vol.197 (1981) 615-616.

3. Apfel R.E., Investigation on the Applicability of Superheated Drop Detector in Neutron Dosimetry, Nucl. Instr. Meth. in Physics Research, Vol.219 (1984) 582-587.

4. Sjafruddin, T. Iguchi, M. Nakazawa, Investigation on the BD's Characteristics as New Type Neutron Detector, Proc. $3^{\text {rd }}$ Scientific Meeting ATOM'94 (1994) 299-305.

5. Biro T. et. al, Acoustic Detection of Neutrons by Bubble Detector, Intl. Jour. of Rad. Appl. and Instrumentation, Part D: Nuclear Track and Radiation Measurements, Vol.17 (1990) 587-589. 